\title{
Manage Humans, not the Environment
}

\author{
J. T. Trevors • M. H. Saier Jr.
}

Published online: 24 February 2009

(C) Springer Science + Business Media B.V. 2009

Environmental management is taught in many courses, at virtually all educational levels, and research articles and books on this important subject will continue to be written at ever-increasing rates. However, after decades of teaching and studying the importance of environmentalism, many people still do not recognize the simple but critical two-sidedness of the environmental coin. These two sides are (1) the excessive and expanding human population and (2) the level of resource consumption per person. Although many teachers and students have concluded that managing the environment is secondary to managing human population growth, there is still little acceptance of this importance precept among the general public, partly because human population restriction is a sensitive issue that many environmental educators are not willing to confront and partly because many people just do not want to hear it or do anything about it. Yet, all of the recognized environmental problems that face us, global warming,

\section{J. T. Trevors}

Department of Environmental Biology,

University of Guelph,

Guelph, ON, Canada N1G 2W1

e-mail: jtrevors@uoguelph.ca

M. H. Saier Jr. ( $\square)$

Division of Biological Sciences, University of California, San Diego,

La Jolla, CA 92093-0116, USA

e-mail:msaier@ucsd.edu chemical and biological pollution, loss of biodiversity, resource wars, energy supplies, ozone depletion, social unrest, hunger, and food shortages/distribution, are directly due to human overpopulation, not the other way around. Yes, all agree, human activities are the cause of most of our environmental problems. Manage humans and their damaging actions, not just "the environment," and we have a chance for sustainability and species survival. This thinking is simple and accurate; it can be illustrated with the following examples.

1. We must decrease production and use of deleterious pollutants of all kinds. Toxins, carbon dioxide and nitrous oxide, free radicalgenerating chlorofluorocarbons, human-made drugs and other chemicals, for example, are killing our biosphere. They upset the Laws of Nature. This is due, almost exclusively, to the increasingly devastating human assault on our common, shared biosphere. Given our current levels of global pollution, we have a decreasing chance for long-term sustainability with biosphere protection.

2. With an estimated 6.8 billion humans currently on Earth (http://www.census.gov/main/www/pop clock.html), and 75 million more (births over deaths) appearing annually, with North Americans accounting for only $5 \%$ of the total population but consuming between $25 \%$ and $30 \%$ of the world's resources, we immediately recognize the two sides 
of the coin. We know we must do something about both.

3. $6,800,000,000$ humans include about 2,000 , 000,000 people living in poverty. For such people, there are essentially no basic human rights; the needs of these people are not being met. Food, water, public health, legal aid, safety/ security, transportation, education, availability of birth control services, shelter, clothing, and transportation are all lacking. These people cannot think long-term; they live only for survival-only for the moment. Their concerns deal with water, food, disease, and premature death, each and every day.

4. We must succeed in decreasing the human population if we are to slow the assault on the Earth's biosphere. Only if we do so, will we have sufficient time, energy, and capability to meet the challenges of global climate change, human and animal pandemics, and conflicts at international, national, communal, and personal levels. We need infrastructure and international cooperation to combat the inevitable spread of preexisting and emerging diseases. Only then can we hope to provide food, shelter, clothing, health care, education, communication, transportation, waste management, and the basic essentials of life.

5. Managing humans requires short-term action and long-term education, particularly on how to manage our reproductive activities. This would be the first and most important step toward becoming responsible world citizens. Progress toward resource consumption limitation will be thwarted if the numbers of humans on Earth continue to increase. Education can provide a dual knowledge-value system that allows people to think globally-long-term-instead of only considering the short-term individual desires for immediate gratification. Everyone must recognize the consequences of unwanted pregnancy and birth. Every child must have a loving, nurturing home. Basic and environmental education will help us to prevent irresponsible resourcedepleting activities as well, but educating a major fraction of a population will unfortunately take decades. We need solutions now!

6. The boom and bust cycles of economic growth are entirely dependent on the resources of our planet. The current economic crisis may never be easily solved because we are at a number (6.8 billion humans) that does not allow restoration of depleted resources that our life styles depend on. It is understood that too many humans with limited resources can never achieve sustainability. The current global economy (2008-2009) is unfortunately a consequence of our resource availability/human numbers predicament. Greed was the new god in our society, but this greedy god will never satisfy the needs of a stable biosphere and the desires of some greedy people in our overpopulated world.

7. Humans are on a direct and fast collision course with global environmental disaster, and we are doing little to avoid the consequences. We must provide the means for fertility restriction so women can choose their family sizes and never be forced into unwanted pregnancy and motherhood. Universal women's rights and human rights must be guaranteed. Remember, women are the victims of assaults, incest, and male domination. In every country where free birth control methods become available, birth rates drop to near replacement levels. This means that high fertility rates are not wanted by the citizens of underdeveloped countries; high fertility is forced upon women everywhere when free contraception and safe abortion services are not available. The wealthy countries must provide free family planning to the entire world. Surprisingly, this would take a mere 30 billion dollars per year. This is nothing compared to the trillions of dollars spent on the Iraq war or the economic bailout in the U.S. alone. Especially for long-term benefit, we must educate the human mind with knowledge, problem-solving skills, and global humane values. Everyone must know and understand that we are all in this together as a singular human species, and only if we work as a world community to solve our problems, do humans have a struggling chance of survival with the other species on our planet.

The current generation of young students will play a critical role in determining the fate of Homo sapiens. Our young people will be confronted with immense and complex, interconnected global problems, even greater than we currently face. This 
against a background of an ever-growing 6.8 billion people. Too many humans on our small planet spell disaster. This generation of young people will be required to solve the problems created by previous careless generations. They must solve problems their parents did not even envision or maybe just denied and ignored. This young generation will be confronted with energy and food shortages, pandemics, economic debt, global climate change, and the interconnected consequences of climate change, all more severe than we have had to confront. And they may have to try to solve these problems with the potential dissolution of the infrastructure that will be required to avoid untold human and biosphere suffering. The only way to prepare this young generation is through proper education that teaches the essentiality of reversing human population growth and excess resource consumption. Sustainability must be a word on the lips of everyone. For the sake of our precious blue planet, we must succeed. Will the new generation be able to relocate coastal cities? Are they prepared to meet the challenges of a hungry planet with the expected energy shortages? Are they to become knowledgeable enough so as to avoid the beguiling efforts of greedy politicians who want them to fight resource wars? The new generation has many monumental choices to make, and they will need all the education, knowledge, insight, imagination, correct values, and problem-solving skills they can obtain. There are immense problems to be solvedor to be ignored - until it is too late.

To help this generation, our vision of current and future hope, we must make a diminishing global human population our first priority, and the restriction of excess global resource consumption our second priority. Education is an absolute necessity and will help, but it is often slow. Anything less than our full effort will mean failure. Those who disagree will slow down the environmental recovery, but after wasting time, as we have for the past years, our doubting colleagues will be forced to reassess their thinking. They will have no choice but to realize they were wrong. The current thoughts and actions of many humans may be an irrational blend of wishful thinking and denial. This condition is simply not an acceptable state. Remember, we add 75 million more humans to our planet every year and the current generation of young people on our planet is the most important generation we need to educate to meet the current and future shared, global challenges. Educate and manage human activities, not just the environment. 